\title{
MENGUKUHKAN KEMBALI PERAN PERPUSTAKAAN SEBAGAI MEDIA SYIAR PENGETAHUAN ISLAM DI BALIK FENOMENA REDUPNYA KEJAYAAN PERPUSTAKAAN ISLAM (YPI-PIP) KABUPATEN KUDUS
}

\author{
Fatma Laili Khoirun Nida \\ Institut Agama Islam Negeri Kudus, Jawa Tengah, Indonesia \\ syakila.elmuna@gmail.com
}

\begin{abstract}
The power of information technology demands the libraries to keep improving themselves following the characteristics of community needs in conducting literacy activities. The inability of the library to balance itself against the pattern will be the trigger of weakening the role of the library in carrying out its function. It is happened in YPI PIP Library of Kudus Regency.Various factors that trigger the deterioration of the library that once had been a pioneer in educating Kudus' community in the era before the 2000s. Therefore, innovationsare required to reinforce the role of YPI PIP library through innovations oriented to the revival of this library, such as to make the library as a center of learning resources which is comprehensive and representative, the use of library as a medium to fulfill the religious social needs of Kudus' communities and to improve excellent service based on information technology as a form of library responsibility to the phenomenon of media transfer. Those efforts are innovations that can be done in order to rebuild the role of YPI PIP library of Kudus Regency as syiar media and science center.
\end{abstract}

Keywords: Library, Media Syiar, Center for Science 


\begin{abstract}
Abstrak
Kekuatan arus teknologi informasi melahirkan tuntutan bagi perpustakaan untuk terus berbenah diri mengikuti karakteristik kebutuhanmasyarakat dalam melakukankegiatan literasi. Ketidakmampuan perpustakaan untuk menyeimbangkan diri terhadap pola tersebut akan menjadi pemicu melemahnya peran perpustakaan dalam menjalankan fungsinya. Sebagaimana yang terjadi pada Perpustakaan YPI PIP Kabupaten Kudus. Beragam faktor yang menjadi pemicu keterpurukan perpustakaan yang dulu pernah menjadi pelopor dalam mencerdaskan kehudupan masyarakat kudus di era sebelum tahun 2000an. Maka diperlukan adanya inovasi untuk mengukuhkan kembali peran perpustakaan YPI PIP melalui inovasi yang berorientasi pada kebangkitan perpustakaan ini, diantaranya adalah menjadikan perpustakaan sebagai pusat sumber belajar yang bersifat komprehensif dan representatif, pemanfaatan perpustakaan sebagai media dalam pemenuhan kebutuhan social keagamaan masyarakat kudus yang religious serta perbaikan kualitas pelayanan prima yang berbasis teknologi informasi sebagai bentuk responsibilitas perpustakaan terhadap fenomena alih media.Upaya tersebut merupakan inovasi yang dapat dilakukan dalam rangka membangun kembali peran perpustakaan YPI PIP Kabupaten Kudus sebagai media syiar dan pusat ilmu pengetahuan.
\end{abstract}

Kata Kunci: Perpustakaan, Media Syiar, Pusat Ilmu Pengetahuan

\title{
A. Pendahuluan
}

Eksistensi perpustakaan sebagai media untuk mencerdaskan kehidupan bangsa merupakan fenomena yang tidak dapat dinafikan. Dalam sebuah sistem pendidikan dimanapun keberadaannya, perpustakaan memiliki daya dukung yang kuat dalam menciptakan keberhasilan pendidikan. Keberadaan perpustakaan sebagai sumber ilmu, sumber pengetahuan dan sumber kearifan tentang hidup dan kehidupan tetap sangat dibutuhkan. Dalam dinamika 
kehidupan manusia yang selalu dihadapkan pada rentetan masalah yang silih berganti, kadang manusia tidak merasa cukup untuk mencari solusi atas permasalahan mereka hanya dengan bertanya kepada manusia lain. Adakalanya manusia merasa menemukan solusi melalui sumber bacaan yang mereka konsumsi sehingga disinilah eksistensi perpustakaan tidak dapat dinafikan.

Di era teknologi yang terus mengalami perkembangan, kebutuhan masyarakat akan pemuasan kebutuhan kognitif melalui perpustakaan kini telah mengalami metamorphosis. Pemenuhan kebutuhan akan pengetahuan melalui peran perpustakaan telah mengalami pergeseran. Perkembangan teknologi yang melaju dengan pesat memaksa perpustakaan untuk turut berperan melakukan evolusi dari pola perpustakaan yang bersifat konvensional menuju perpustakaan yang berintegrasi dengan teknologi.

Keterbukaan perpustakaan untuk melakukan proses pembaharuan sebagai upaya untuk menciptakan kenyamanan dan kemudahan bagi masyarakat dalam mengakses informasi dan pengetahuan pada akhirnya akan berimbas pada kemajuan perpustakaan itu sendiri, dan berujung pada keberhasilan roda pembangunan intelektual masyarakatnya. Beberapa perpustakaan di Indonesia telah mampu melakukan upaya reformasi dari perpustakaan tradisional menuju perpustakaan digital sebagaimana yang dilakukan oleh perpustakaan IAIN Aalaudin Makasar, dimana manfaat yang diperoleh bagi pengguna adalah mempermudah penelusuran informasi, menghemat waktu, tenaga. Manfaat bagi perpustakaan adalah mempermudah dalam mengolah bahan pustaka, meringankan pekerjaan, menghemat tenaga, serta bahan pustaka dapat dimanfaat lebih optimal ${ }^{1}$. Fenomena tersebut menjadi tantangan yang tidak sederhana bagi setiap lembaga perpustakaan dan seperangkat elemen yang terdapat di dalamnya

1 Triana Santi, "Penerapan Teknologi Informasi Untuk Meningkatkan Kualitas Layanan Perpustakaan IAIN Sumatera Utara," Jurnal IQRA' Vol.2, No. 2 (2008): 32. 
untuk terus bersaing dengan beragam sistem penyedia informasi yang berkembang bersama teknologi saat ini.

Salah satu lembaga perpustakaan yang cukup terdampak dari kemajuan teknologi adalah Perpustakaan Islam yang dibawah naungan Yayasan Pendidikan Islam dan Penyiaran Ilmu Pengetahuan kab Kudus. Kondisi perpustakaan pertama di Kudus yang berdiri sejak tahun 1975 tersebut terlihat cukup memilukan, ibaratnya hidup segan mati tak mau. Koleksi buku yang dimiliki perpustakaan tidak lagi memiliki daya tarik bagi pengunjung. Kondisi gedung 60\% mengalami kerusakan dan tidak difungsikan lagi. Dalam sebuah pernyataan yang disampaikan oleh informan yang sekaligus penjaga perpustakaan menyatakan bahwa redupnya kejayaan perpustakaan ketika tak lagi memiliki daya dukung dari masyarakat baik terkait donatur yang sebelumnya diperoleh dari pihak swasta maupun pemerintah, dampaknya adalah pada penyediaan fasilitas perpustakaan yang sangat minim dan terkesan usang. Buku-buku bacaan yang sudah kuno, lusuh, dan banyak yang rusak membuat masyarakat enggan untuk hadir di dalamnya. Terlebih di era teknologi yang saat ini, dimana perpustakaan selalu dilengkapi dengan fasilitas yang berintegrasi dengan teknologi, sementara YPI tidak mampu untuk mensejajarkan diri melalui upaya peningkatan mutu pelayanannya. Praktis sejak tahun 2010, saat semakin maraknya e-library dan semua layanan informasi yang berbasis teknologi internet, perpustakaan YPI PIP tidak lagi diminati masyarakat. ${ }^{2}$

Fenomena di atas sangat memprihatinkan mengingat perpustakaan YPI PIP ini pernah menjadi bagian dari sejarah perkembangan keilmuan di Kabupaten Kudus. Perpustakaan YPI PIP kabupaten Kudus merupakan perpustakaan pertama yang didirikan di kota Kretek pada tahun 1975. Kehebatan perpustakaan ini tidak hanya pada perannya dalam menyediakan

${ }^{2}$ Imam Arwindra, "Perpustakaan Umum Pertama di Kudus Riwayatmu Kini," Seputar Kudus (blog), 2017, http://seputarkudus.com/2017/03/ perpustakaan-umum-pertama-di-kudus-riwayatmu-kini.html. 
fasilitas pendidikan dan pengetahuan masyarakatnya melalui koleksi bacaan yang disediakan, namun lebih dari itu, lembaga ini dahulu merupakan pusat kegiatan sosial keagamaan yang cukup kontributif dalam mendukung pembangunan intektual dan spiritual umat. Terbukti dalam hasil wawancara dengan informan, bahwa perpustakaan YPI PIP menjadi pusat bagi kegiatan santunan fakir miskin dan anak yatim setiap tahunnya. Dengan letaknya yang sangat strategis di pusat perkotaan tepatnya di dekat Alunalun Kudus dan Masjid Agung Kudus, perpustakaan ini sempat menjadi pelopor bagi perkembangan kehidupan sosial keagamaan masyarakat muslim Kudus di saat itu. Selain kegiatan santunan fakir miskin dan anak yatim, di lembaga ini pula sering dilangsungkan kegiatan seminar, diskusi, dan konsultasi skripsi bagi mahasiswa mengingat perpustakaan tersebut dahulunya merupakan elemen pendukung bagi keberlangsungan pendidikan di dua perguruan tinggi saat itu, yakni STAIN Kudus dan Universitas Darul Ulum Islamic Centre Sudirman (UNDARIS).

Kini, perpustakaan yang memiliki koleksi sekitar 3000 buku tersebut seolah mewakili kondisi keterpurukan dunia literasi Islam di kabupaten Kudus. Banyak faktor yang menjadi kontribusi redupnya kejayaan perpustakaan YPI PIP tersebut, menjadi tugas besar bagi elemen masyarakat untuk mengukuhkan kembali kekuatan perpustakaaan YPI PIP Kab Kudus melalui beragam inovasi yang dihasilkan dari kajian teoritis maupun empiris yang berorientasi pada upaya rekonstruksi lembaga perpustakaan yang mampu berintegrasi dengan karakteristik budaya literasi masyarakat di era teknologi yang sedang berlangsung.

Dari tulisan ini, diharapkan akan memberi kontribusi bagi upaya penguatan kembali peran perpustakan YPI PIP sebagai pusat pembangunan kecerdasan masyarakat dengan menjadikan perpustakaan tidak hanya sebagai wahana penyedia informasi pengetahuan, namun juga menjadi motor bagi kegiatan syiar keagamaan dengan melakukan inovasi yang sesuai dengankebutuhan sosial keagamaan yang berlaku di masyarakat setempat. 


\section{B. Pembahasan}

\section{Peran dan Fungsi Perpustakaan Dalam Pendidikan dan Sumber Ilmu Pengetahuan}

Bagaimanapun juga eksistensi perpustakaan dalam meningkatkan kemajuan intelektual masyarakat tidak akan dapat tergantikan. Perpustakaan sebagai penyedia informasi pengetahuan yang memiliki tugas yang kompleks diantaranya sebagai pusat belajar mengajar, membantu peserta didik untuk memperjelas danmemperluas pengetahuannya, mengembangkan minat, bakat dan kegemarannya, kemampuan dan kebiasaan membaca yang menuju kebiasaan yang mandiri, membiasakan peserta didik untuk mencari informasi, tempat rekreasi dan tempat yang dapat memperluas kesempatan belajar peserta didik serta berperan memberi ketrampilan menemukan, menjaring, menilai informasi, dan menarik kesimpulan dari penelitian yang dilakukannya. ${ }^{3}$

Demikian juga, fungsi perpustakaan baik di lingkungan sekolah maupun di luar sekolah menjadikan peran perpustakaan akan terus dibutuhkan dalam mewarnai dinamika perubahan kehidupan yang terjadi di masyarakat. Secara umum, perpustakaan memiliki fungsi yang cukup komprehensif yang diantaranya:

a. Khazanah Penyimpan Karya Manusia

Fungsi ini sangat diutamakan oleh perpustakaan nasioal dan perpustakaan daerah, dimana perpustakaan berfungsi sebagai tempat menyimpan arsip bagi produk-produk yang dihasilkan oleh masyarakat sebagai khasanah budaya bangsa baik berupa karya tulis, karya cetak dan karya rekam manusia. Sedangkan perpustakaan lain seperti perpustakaan umum, perpustakaan sekolah, perpustakaankhusus dan perpustakaan pribadi atau keluarga serta tamanbacaan

3 Rahmananta, Pedoman Penyelenggaraan Perpustakaan sekolah; Petunjuk Untuk Membina, Memakai dan memelihara Perpustakaan di Madrasah (Jakarta: Perpustakaan Nasional RI, 1995), 7. 
atau jenis perpustakaan lain memfokuskan fungsinya sebagai layanan informasi.

b. Sumber Informasi

Secara tradisional perpustakaan lebih menitik beratkan kepada informasi dari koleksi yang dimilikinya. Namun dewasa ini informasi tersebut dapat juga bekerjasama dengan perpustakaan lain misalnya melalui kerjasama antar perpustakaan (inter library loan) atau jaringan. Untuk mendukung kerjasama maka masing-masing perpustakaan harus dilengkapi dengankoleksi yang memadai.

c. Fungsi Rekreasi

Fungsi ini dapat dikembangkan oleh peran perpustakaan umum dan perpustakaan sekolah. Melalui kegiatan membaca akan menjadi upaya untuk menghilangkan kejenuhan bagi masyarakatsekaligus rekreasi batiniah dengan membaca.

d. Fungsi Pendidikan,

Fungsi ini mendukung pendidikan formal dan nonformal sangat dominan pada perpustakaan sekolah dan perguruan tinggi, sedangkan perpustakaan umum lebih berfungsi dalam mendukung pendidikan informal.

e. Fungsi Budaya.

Fungsi ini lebih kuat diperankan oleh perpustakaan Nasional sebagai lembaga deposit yang diwajibkan menyimpan dan melestarikan bahan pustaka. Disamping itu, perpustakaan umum seharusnya juga melestarikan budaya lokal terutama yang terekam oleh berbagai media atau bahan pustaka. Budaya lokal kadang terwujud dari bentuk bangunan perpustakaan serta penyediaan ruang untuk mengadakan berbagai kegiatan budaya.

f. Fungsi Penelitian 
Dalam siklus kegiatan penelitian, peneliti memerlukan informasi untuk mengetahui apa yang sudah, sedang dan apa yang harus diteliti. Perpustakaan diharapkan dapat memenuhi kebutuhan informasi peneliti. Hasil penelitian sebelumnya yang dihimpun, disimpan dan yang disediakan perpustakaan adalah bermanfaat bagi peneliti berikutnya. Penelitian dan pengembangan (research and development) merupakan fondasi untuk mencapai kemajuan dan dalam siklus transfer informasi tersebut memperlihatkan mata rantai antara penelitian, penerbitan, pengadaan oleh lembaga informasi, serta pemanfaatan koleksi oleh pemakai yang kemudian menghasilkan penelitian lagi.

g. Fungsi Pengambilan Keputusan

Fungsi ini sangat dominan diperankanoleh perpustakaan khusus, dimana dalam banyak hal koleksi perpustakaan dapat dijadikan sebagai bahan atau rujukan dalam pengambilan keputusan. Data atau laporan masa lalu dapat dijadikan sebagai bahan pertimbangan. Adapun data atau laporan tersebut mampu disediakan oleh perpustakaan sebagai sumber rujukan tertulis sehingga keputusan tidak hanya diambil berdasarkan opini semata ${ }^{4}$.

\section{Karaketristik Perpustakaan Indonesia}

Membincangkan karakteristik perpustakaan di Indonesia, tentunya tidak dapat terlepas dari fenomena adanya perubahan yang terjadi dalam dinamika perkembangan perpustakaan di era tradisional dan modern sebagaimana yang telah berlangsung hingga sekarang. Kebutuhan perpustakaan tradisional untuk bersegera menselaraskan dengan karakteristik perpustakaan modern tidak dapat diabaikan pemenuhannya. Hal tersebut merupakan salah

${ }^{4}$ Hermawan dan Zulfikar, Etika Kepustakawanan; suatu Pendekatan Terhadap Kode'Etik Pustakawan Indonesia (Jakarta: Sagung Seto, 2010). 
satu upaya strategis agar keberlangsungan perpustakaan tradisional tidak mengalami kelesuan bahkan tenggelam digilas oleh peradaban. Menurut teori perpustakaan, perpustakaan bisa dilihat dari 3 jenis pendekatan yaitu: pendektan infrastruktur (gedung), pendekatan content (koleksi) dan pendekatan organisasi (institusi pengelola). Dan karakteristik perpustakaan tersebut dijelaskan dalam tabel di bawah ini ${ }^{5}$ :

Tabel 1: Karakteristik Perpustakaan

\begin{tabular}{llll}
\hline \multicolumn{1}{c}{ Perpustakaan } & \multicolumn{1}{c}{ Infrastruktur } & \multicolumn{1}{c}{ Content } & \multicolumn{1}{c}{ Organisasi } \\
\hline Dulu (1980-2000) & $\begin{array}{l}\text { Rak buku tinggi, } \\
\text { tebal, kayu coklat }\end{array}$ & $\begin{array}{l}\text { Buku ilmiah, } \\
\text { fiksi, non-fiksi } \\
\text { sesuatu yang }\end{array}$ & \\
& & Pemerintah \\
& & \\
& & serius & \\
\hline Sekarang (2000- & Full Color, & -buku, non & Pemerintah, \\
2020) & Pencahayaan & individu, \\
& bagus, minimalis, e-journal, & swasta, \\
& modern & e-book, virtual & kelompok \\
\hline Masa depan & Di rumah & virtual & Bebas \\
(2020-2040) & & & \\
\hline
\end{tabular}

a. Perpustakaan Indonesia dahulu dan sekarang

Karakteristik perpustakaan di Indonesia pun demikian adanya. Sebagaimana yang digambarkan dalam table di atas, bahwa keberadaan alih mediapun telah menjadi bagian dari fenomena perpustakaan di Indonesia. Fenomen Yayasan Perpustakaan Islam dan Pusat Pengembangan Ilmu Pengetahuan kabupaten Kudus merupakan wajah yang mewakili bagaimana karakteristik perpustakaan tradisional di Indonesia di masa lalu. Kegagalan perpustakaan YPI -PIP untuk melakukan alih media sebagai bentuk upaya adaptasi terhadap dorongan transformasi perpustakaan

${ }^{5}$ Anonim, "Perpustakaan Doeloe, Sekarang dan yang Akan Datang," YPPI (Yayasan Pengembangan Perpustakaan Indonesia (blog), diakses 2 Juli 2018, http://pustakaindonesia.org/yppi/2013/11/21/perpustakaan-doeloe-sekarangdan-yang-akan-datang/. 
yang tidak bisa diabaikan menjadikan pemicu keterpurukan dari perpustakaan tersebut.

Persoalan yang sering dihadapi oleh pengguna perpustakaan tradisional adalah keterbatasan koleksi dan kurang maksimalnya pelayanan. Hal ini mengakibatkan pengguna menjadi tidak nyaman untuk berlama-lama di perpustakaan. Alih-alih ingin mendapatkan pencerahan lewat literatur yang tersedia, justru yang didapatkan adalah beban psikologis yang sangat berat karena apa yang diharapkan tidak sesuai dengan kenyataan yang didapatkan. Maka perlu adanya penyelarasan sistemik antara perpustakaan sebagai lembaga pengetahuan dengan sistem sosial budaya mutakhir yang sekarang ini baru berlangsung. ${ }^{6} \mathrm{Hal}$ ini yang belum bisa diupayakan oleh perpustakaan YPI PIP Kudus. Dalam hasil wawancara informan menjelaskan pelayanan perpustakaan masih bersifat manual. Begitu juga koleksi buku yang berjumlah sekitar 3000 an masih banyak diwarnai oleh buku-buku koleksi lama dan itupun secara fisik kondisinya sangat memprihatinkan. Pengunjung hanya sebagian kecil dan nyaris tidak ada dalam setiap harinya disebabkan oleh keterbatasan keadaan tersebut. Ditambah lagi hal yang berbeda terjadi di luar sana, dimana layanan perpustakaan digital, e-book, e-jurnal begitu mudahnya diakses oleh masyarakat. Beberapa pengunjung yang hadir biasanya lebih karena mendapat tugas dari sekolahnya, danitupun tidak setiap hari terjadi. Ketidakpedulian pemerintah dan masyarakat menjadi pelengkap factor terpuruknya perpustakaan.

Pada dasarnya, keterbukaan perpustakaan konvensional untuk bertransformasi menjadi perpustakaan modern telah banyak dijumpai di Indonesia. Dan terbukti bahwa upaya transformasi tersebut membuahkan hasil yang cukup memuaskan bagi perkembangan dunia literasi di Indonesia. Perpustakaan daerah Sumenep misalnya, merupakan salah satu wajah perpustkaan

${ }^{6}$ Saefudin, "Strategi Pengembangan Perpustakaan Perguruan Tinggi Dalam Memenuhi Kebutuhan Informasi Di Era Digital (Sebuah Pandangan Sosiologis atas Fenomena Spiritual Seekers Di Dunia Maya)," Journal Libraria Vol. 4. No. 1 (2016). 
di Indonesia yang berhasil melakukan transformasi menjadi perpustakaan yang berbasis teknologi informasi. Perpustakaan daerah tersebut tidak hanya menjalankan perannya sebagai penyedia informasi secara manual maupun digital namun juga mampu memberi manfaat sebagai pusat kegiatan masyarakat yang didukung oleh sarana danprasarana teknologi informasi yang difasilitasi Perpustakaan daerah. Demikian juga dengan yang dilakukan oleh Perpustakaan Nasional Republik Indonesia yang telah mampu melakukan transformasi dengan mengedepankan layanan berkualitas berbasis Teknologi Informasi dan Komunikasi (TIK) sebagai upaya untuk menghasilkan pelayanan prima. ${ }^{7}$ Fenomena ini menjadi gambaran bahwa perpustakaan di Indonesia terus melaukan perbaikan dan berbenah diri untuk mempertahankan eksistensinya sebagai penggerak dinamika pembangunan intelektual anak bangsa.

b. Budaya Baca Masyarakat Indonesia

Dalam Undang-Undang nomor 20 tahun 2003 tentang Sistem pendidikan Nasional pada pasal4 ayat5 menyatakan bahwa "prinsip penyelenggaraan pendidikan adalah dengan mengembangkan budaya membaca, menulis, dan berhitung bagi segenap warga masyarakat". Namun kenyataan menunjukan bahwa budaya membaca masyarakat Indonesia masih tergolong lemah. Data yang dikeluarkan oleh Badan Pusat Statistik pada tahun 2012 dapat dijadikan gambaran bagaimana minat baca bangsa Indonesia. Dari penelitian tersebut menjelaskan bahwa 91,68\% penduduk Indonesia yang berusia 10 tahun ke atas lebih menyukai menonton televisi dan hanya sekitar 17,66\% yang menyukai membaca dari berbagai sumber bacaan baik buku, majalah, dan surat kabar. Demikian juga data yang diperoleh UNESCO pada 2012 yang menunjukkan bahwa indeks minat baca masyarakat Indonesia baru mencapai angka 0,001 yang artinya dari setiap 1000 orangIndonesia hanya ada seorang saja yang memiliki minat baca. Survey terakhir dalam "Most Littered Nation in the World" yang

\footnotetext{
${ }^{7}$ Visi Pustaka, Juni 2005.
} 
dilakukan olehCentral Connecticut State 'University pada Maret 2016 menunjukkan peringkat Indonesia ada pada nomor 60 dari 61 negara dalam hal minat bacanya. ${ }^{8}$ Data di atas menjadi gambaran bahwa bangsa kita dalam kondisi lemah dalam kemampuan literasinya yang akan berdampak pada rendahnya daya saingdi dunia global.

Minat baca seseorang dapat diartikan sebagai kecenderungan hati yang tinggi pada seseorang terhadap sumber bacaan tertentu. Selain itu, minat baca merupakan kecenderungan jiwa yang mendorong seseorang untuk berbuat sesuatu terhadap membaca. Minat baca ditunjukkan dengan keinginan yang kuat melakukan kegiatan membaca. Minat membaca senantiasa membuat seseorang merasa haus akan bacaan dan minat membaca akan berpengaruh terhadap ketrampilan membaca. Terdapat 5 dimensi yang bisa digunakan untuk mengetahui minat baca seseorang yakni ; (1) Kunjungan ke Perpustakaan, (2) frekwensi membaca, (3)waktu membaca, (4) tujuan membaca, (5) kesenangan dan kebutuhan membaca. ${ }^{9}$

Rendahnya minat baca masyarakat Indonesia saat ini merupakan salah satu kotributor dari permasalahan yang dihadapi oleh sebagian besar perpustakaan di Indonesia dalam rangka mempertahankan keberlangsungan kiprahnya. Minimnya akses pada pustaka dan budaya masyarakat yang lebih mengandalkan budaya tutur (lisan) menjadikan masyarakat dalam upaya untuk memenuhi kebutuhan informasi terbiasa tidak mengandalkan teks tertulis. Informasi penting, berita-berita terbaru, isu dan gosip tersebar secara lisan dari mulut ke mulut. Pada akhirnya masyarakat lemah dalam hal dokumentasi tertulis peristiwa dan hal-hal penting dalam sejarah. Dalam kajian lain, jadilah kita sebagai masyarakat yang meremehkan pentingnya dokumentasi tertulis, dan pada akhirnya lemah ingatan pada hal-hal penting

${ }^{8}$ Elga Andina, "Memotivasi Minat Baca," Info Singkat Kesejahteraan Sosial, November 2016.

9 Endang Saepuddin, “Tingkat Budaya Membaca masyarakat," Jurnal Kajian Informasi dan Perpustakaan Vol.3, No. 2 (Desember 2015): 274. 
yang tak terdokumentasikan dengan baik. Latar budaya lisan itulah yang agaknya menjadi salah satu sebab lemahnya budaya baca masyarakat, termasuk minat pada pustaka dan perpustakaan dalam memenuhi kebutuhan informasi dan ilmu pengetahuan. Berdasarkan fenomena tersebut, maka terbentuk budaya tutur yang kian kokohnya sehingga budaya mencari dan mendapatkan informasi secara cepat dan instan lebih diminati dari sumber radio dan televisi. Setelah era kejayaan radio sebagai media komunikasi yang merakyat pascakemerdekaan, maka televisi kemudian telah menjadi satu-satunya media informasi yang paling massif dalam memengaruhi budaya masyarakat. ${ }^{10}$

Melihat realita yang berkembang di masyarakat kita saat ini, menunjukan bahwa betapa televisi dan internet menjadi salah satu unsur yang berperan kuat dalam menciptakan opini, menyediakan informasi, dan membentuk karakter masyarakat baik mereka yang masih diusia kanak-kanan maupun dewasa. Padahal, keberadaan media informasi semacam televisi dan media yang bersifat visual lainnya seperti gadget adalah semakin melemahkan budaya baca masyarakat itu sendiri. Selanjutnya Darmaningtyas menjelaskan bahwa televisi melemahkan budaya analisis dalam ranah kognitif penontonnya, karena otak dimanjakan dengan informasi yang bersifat instan. Berbeda dengan buku dan teks, menggali hakikat makna, dan bermain imajinasi. Hal ini menyebabkan otak terlatih untuk menganalisis dan mengkritisi teks, otak tidak akan dimanjakan dan semakin kuat daya analisisnya. Walaupun begitu, masyarakat yang sebagian besar bermental instan dan ingin dimanja tentu tidak mempedulikan hal itu, mereka tetap lebih memilih televisi daripada buku. Ketika masyarakat sebagian besar sudah memiliki persepsi kurang penting pada bahan pustaka, terlebih lagi perpustakaanpun dianggap sama. Perpustakaan tidak menjadi tujuan utama masyarakat dalam mencari dan mendapatkan informasi. ${ }^{11}$

10 Darmaningtyas, Perpustakaan dalam Dinamika Pendidikan dan Kemasyarakatan (Semarang: UNIKA Soegijapranata, 2008), 75.

${ }^{11}$ Darmaningtyas, 76. 
Fenomena inilah yang berkembang pada sebagian masyarakat Kudus. Berdasarkan informasi dari petugas pengelola perpustakaan YIP PIP, menutunnya minat baca masyarakat khususnya generasi muda disebabkan banyak faktor yang salah satunya adalah karena gencarnya media internet. Kemudahan akses masyarakat terhadap sumber informasi yang disediakan oleh beragam aplikasi internet menyebabkan masyarakat enggan untuk mengunjungi perpustakaan yang notabene hanya menyediakan informasi dalam bentuk layanan secara manual. Rendahnya minat baca yang berkorelasi dengan menurunnya jumlah pengunjung perpustakaan juga diperburuk oleh penyediaan sarana dan prasarana perpustakaan YIP PIP yang terkesan out of date. Kesan kuno tampak dari penyediaan koleksi buku yang telah banyak mengalami kerusakan, usang dan sedikit varian. Hal inilah yang menjadi sisi terpenting dari lemahnya daya saing perpustakaan YIP PIP untuk menarik animo masyarakat dan secara tidak langsung juga akan berimbas kembali pada semakin rendahnya minat baca masyarakat Kudus. Padahal, sebagaimana dijelaskan di atas bahwa kebutuhan penyediaan informasi yang berbasis IT merupakan hal yang tidak dapat ditawar lagi mengingat saat ini kontribusi teknologi informasi merupakan unsur yang tidak dapat dipisahkan dari semua aspek kebutuhan manusia, termasuk dalam dinamika pengayaan intelektual mereka. Pola pemenuhan kebutuhan sumber bacaan yang terintegrasi dengan teknologi akan mempermudah masyarakat untuk mengaksesnya yang secara berkesinambungan akan menjadi stimulasi dalam meningkatkan minat baca masyarakat itu sendiri.

Rendahnya minat baca yang diduga menjadi salah satu factor menurunnya jumlah pengunjung perpustakaan YIP PIP sebenarnya dapat dijadikan sebagai salah satu inspirasi bagi pengelola perpustakaan untuk melakukan inovasi secara kreatif dalam mengelola perpustakaan agar fungsi perpustakaan tidak hanya sebatas penyedia koleksi buku namun juga pusat sumber belajar. Pada hakikatnya, eksistensi perpustakaan tidak hanya 
sebagai tempat penyediaan koleksi buku dan dokumentasi yang bersifat tertulis lainnya, namun juga sebagai wahana sember belajar yang bersifatt komprehensif. Hal ini sebagaimana yang ditegaskan dalam Undang-Undang Nomor 20 tahun 2003 tentang Sistem Pendidikan nasional yang menyebutkan bahwa pembelajaran adalah proses interaksi peserta didik dengan pendidik dan sumber belajar dalam suatu lingkungan belajar. Pendidikan tidak akan terselenggara dengan baik apabila para pendidik dan peserta didik tidak didukung dengan sumber belajar yang diperlukan untuk penyelenggaraan kegiatan belajar mengajar yang bersangkutan.

Adapun istilah sumber belajar (learning resource) umumnya diketahui hanya masuk pada perpustakaan dan buku. Padahal secara tidak terasa apa yang digunakan dalam pembelajaran baik berupa data maupun benda termasuk dalam kategori sumber belajar. Sumber belajar adalah semua sumber baik berupa data, orang, maupun wujud tertentu yang dapat digunakan dalam belajar baik secara terpisah maupun secara terkombinasi sehingga mempermudah peserta didik untuk belajar atau mencapai kompetensi tertentu. ${ }^{12}$

Pernyataan di atas menyadarkan kita akan paradigma yang selama ini berkembangdi tengah masyarakat awam bahwa perpustakaan adalah tempat berkumpulnya sumber informasi yang hanya berupa buku dan dokumen secara fisik saja namun lebih dari itu fungsi perpustakaan akan lebih maksimal apabila kiprah para kaum intelektual, pelajar, mahasiswa, dosen, dan lainnya untuk menjadikan perpustakaan sebagai pusat dari kegiatan keilmuan yang memberi kontribusi pada penguatan kehidupan sosial secara komprehensif. Untuk itu perlu adanya upaya penyadaran terhadap masyarakat bahwa perpustakaan sebagai learning centre (pusat sumber belajar). Upaya ini adalah langkah awal untuk menguatkan budaya baca tulis ditengah kuatnya budaya lisan. Kekuatan budaya

12 Tafrikhuddin, "Antologi Ilmu Perpustakaan dan Informasi" (Pascasarjana UIN Sunan Kalijaga, 2015), 18. 
literasi inilah yang akan menjadikan masyarakat Indonesia sebagai kelompok masyarakat dengan mina baca yang tinggi.

\section{Rekonstruksi Perpustakaan Berbasis Kearifan Lokal; Sebuah Ide Inovatif bagi Pengembangan Perpustakaan YPI PIP.}

a. Masyarakat Kudus Sebagai Masyarakat religious; Sebuah Peluang

Masyarakat Kabupaten Kudus adalah masyarakat yang religious. Kudus merupakan sebuah kota yang terkenal dengan julukannya sebagai Kota Santri. Berdasarkan data Kementrian Agama Kabupaten Kudus tahun 2015 terdapat 68 pondok pesantren dengan jumlah santri sebanyak 13.510 orang serta 92 Kyai dan 874 ustadz. Banyaknya jumlah pesantren dan santri menjadi salah satu indikator bahwa Kudus memang layak dijuluki sebagai kota yang religius. Religiusitas masyarakat Kudus tercermin dari sikap dan perilaku sehari-hari yang selalu menjunjung tinggi kerukunan, ketenangan, ketentraman dankedamaian. Filsafat hidup yang diwariskan Sunan Kudus atau Raden Ja'far Shodiq sebagai leluhur masyarakat Kudus adalah GUSJIGANG. Falsafah GUSJIGANG yang merupakan singkatan dari baGUS, ngaJI, berdaGANG merupakan ruh yang harus dijaga dalam rangka meningkatkan kualitas pribadi serta ekonomi sebagai bekal hidup. Religiusitas masyarakat Kudus dalam kehidupan sehari-hari turut membentuk budaya masyarakat Kudus ${ }^{13}$.

Berdasarkan hasil wawancara yang dilakukan peneliti terhadap informan dengan menghimpun beberapa data dari sumber pustaka lain, religiusitas masyarakat Kudus yang masih cukup kuat inilah merupakan celah atau peluang bagi masyarakat Kudus khususnya pengelola perpustakaan YIP PIP untuk menghidupkan kembali keberadaan perpustakaan YIP PIP yang ibaratnya sedang dalam kondisi mati suri. Berdasarkan informasi bahwa dahulunya perpustakaan tersebut semarak dengan kegiatan syiar keagamaan

${ }^{13}$ Erik Ismaya, Irfa'i Faturrahman, dan Deka Setiawan, "Makna dan Nilai Buka Luwur Sunan Kudus (Sumbangan Pemikiran Mewujudkan Visi Kampus Kebudayaan)," Jurnal Kredo Vol.1, No.1 (Oktober 2017): 46. 
yang berwujud diskusi, kegiatan santunan dan pusat kegiatan pendukung perkembangan intelektual bagi pelajar dan mahasiswa di Kudus khususnya. Hausnya masyarakat Kudus akan pemenuhan kebutuhan penguatan religiusitas mereka dapat terpenuhi oleh sarana penyediaan sumber bacaan berupa buku-buku keagamaan disaat itu. Dan tidak cukup dengan sekedar koleksi buku, bahkan layanan diskusi, seminar dengan narasumber yang kompeten menjadi salah satu sumber pemenuhan kebutuhan spiritual dan keilmuan mereka.

Untuk itu, pengalaman masa keemasan perpustakaan YIP PIP di masa sebelum tahun 2000an sebenarnya dapat dibangun kembali dengan bentuk yang menyesuaikan karakteristik perilaku masyarakat dalam pemenuhan penguatan religiusitas mereka dimasa milineal saat ini. Konsistensi masyarakat Kudus dalam kehidupan dan perilaku beragama mereka akan menjadi pijakan dalam melakukan kajian-kajian yang berorientasi pada penguatan kembali peran perpustakaan YIP PIP dalam melakukan pelayanan dibidang pengauatan intelektual keagamaan masyarakat Kudus. Salah satu karakteristik beragama masyarakat Kudus yang sangat kuat adalah minat mereka terhadap kegiatan majlis ta'lim. Perpustakaan dapat turut mengambil alih fungsi masjid dan mushola yang selama ini menjadi ajang dilaksanakannya kegiatan keagamaan. Upaya ini akanmenjadi jalan bagi pegiat perpustakaan untuk mengenalkan pada masyarakat tentang fungsi perpustakaan sebagai sumber belajar (learning centre).

Penguatan peran perpustakaan YIP PIP sebagai pusat sumber belajar ilmu pengetahuan dan penyiaran Islam akan lebih maksimal bila mampu menjalin kolaborasi dengan pusat-pusat kegiatan pendidikan sosial dan keagamaan di Kabupaten Kudus,seperti majlis ta'lim, masjid, madrasah, perguruan tinggi agama, pesantren serta lembaga-lembaga yang berorientasi pada pembangunan mental beragama masyarakat Kudus khususnya. Integrasi antara perpustakaan dengan lembaga pendidikan keagamaan akan menjadi peluang untuk menguatkan peran perpustakaan. Tentu 
saja hal ini juga diimbangi dengan penyediaaan sarana prasarana yang representatif seperti perangkat IT, pustakawan yang melek teknologi, dan kualitas pelayanan prima yang berbasis teknologi informasi. Upaya rekonstruksi tersebut akan menjadi magnet tersendiri bagi masyarakat untuk berkunjung ke perpustakaan yang memiliki karakteristik spesifik sebagaimana budaya yang berlaku di masyarakatnya.

b. Menjadikan Perpustakaan Sebagai Pusat Sumber Belajar dan Pusat Syiar dan wahana pemenuhan kebutuhan Sosial Keagamaan

Fungsi dan peran perpustakaan sebagai sumber belajar merupakan salah satu kunci dari upaya penguatan kembali peran perpustakaan YIP PIP saat ini. Sumber belajar mencakup apa saja yang dapat digunakan setiap orang untuk belajardanmenampilkankompetensinya. Dalam hal ini sumber belajar dapat meliputi pesan, orang, bahan,alat, teknik, dan lingkungan. Trucker mendefinisikan pusat sumber belajar dengan istilah media center, dengan pengertian suatu departemen yang memberikan fasilitas pendidikan, pelatihan dan pengenalan melalui produksi bahan media (sperti slide, transparansi overhead, filmstrip, videotape, film, dan lain-lain) dan pemberian pelayanan penunjang (seperti sirkulasi peralatan audiovisual, penyajian program video, pembuatan katalog, dan pemanfaatan layanan sumber belajar pada perpustakaan). ${ }^{14}$

Sebagaimana telah dijelaskan di atas, bahwa masyarakat dengan budaya baca sebenarnya dapat dibangun dari minat terhadap perpustakaan itu sendiri. Eksistensi perpustakaan yang representatif, dengan pelayanan berbasis teknologi serta kualitas pustakawan yang kompeten untuk mendukung pelayanan prima akan menjadikan perpustakaan sebagai wahana yang terus menerus menarik kehadiran masyarakat untuk mengunjunginya.

${ }_{14}$ Trucker R. N., The Organization and Management of Educational Technology (New patterns of learning) (London: Croom Helm, 1979), 1. 
Perpustakaan YIP PIP sebenarnya memiliki potensi yang cukup besar untuk menjadi pusat kegiatan keilmuan dan syiar bagi masyarakat Kudus. Bahkan lebih dari itu, peran perpustakaan YIP PIP dapat dikembangkan menjadi pusat kegiatan pendidikan dan pelatihan dan apapun yang berorientasi pada penguatan kualitas masyarakat Kudus khususnya. Bila ditinjau dari posisi perpustakaan yang berada di pusat kota tepatnya di seberang alun-alun Kudus dan nyaris berdampingan dengan Masjid Agung Kudus, maka perpustakaan YIP PIP memiliki peluang menarik minat masyarakat untuk mengembangkan kualitas dankarakter masyarakat dengan berbasis budaya mereka. Falsafah GUSJIGANG dapat dijadikan acuan untuk diwujudkan dalam bentuk kegiatan-kegiatan diskusi keilmuan, pelatihan kewirausahaan dan kegiatan-kegiatan yang bermuatan pembentukan karakter masyarakat melalui pemanfaat perpustkaan YIP PIP. Kontribusi masyarakat sangat dibutuhakan untuk ikut serta di dalam revitalisasi fungsi perpustakaan sebagai pusat sumber belajar bagi masyarakat. Keberadaan Masjid Agung Kudus yang selama ini menjadi pusat kegiatan keagamaan akan sangat dibutuhkan untuk bersinergi dengan perpustakaan YIP PIP yang sejak awal telah memiliki misi syiar melalui platform yang dimilikinya sebagai pusat ilmu pengetahuan dan penyiaran Islam.

Ide ini sejalan dengan apa yang pernah disampaikan Fuad Hasan dalam seminar yang bertema "Perpustakaan sebagai Agen Perubahan Sosial". Menurut beliau kehadiran perpustakaan merupakan tuntutan mutlak bagi setiap masyarakat yang ingin mejadikan warganya bukan hanya sekedar kaya informasi (well informed) dan terdidik baik (well educated) melainkan lebih memiliki kecanggihan akan wawasannya (sophisticated). Maka perpustakaan tidak hanya sebagai "penggudangan buku" melainkan menjadi tempat penyimpanan informasi, edukasi dan rekreasi. Ketiga kebutuhan ini dapat dilayani oleh perpustakaan yang menyesuaikan koleksinya dengan minat masyarakatnya. Tentu sajaberbagai kemungkinan tersebut sebaiknya didahului dengan mempelajari apa yang menjadi minat dan kepentinganmasyarakat 
setempat terutama yang berkaitan dengan usaha peningkatan kualitas kehidupan warganya. Lebih baik lagi bila pemilihan koleksi buku dapat untuk menambah sumber penghasilan (income generating) dan atau dapat membuka lapangankerja (employment generating). ${ }^{15}$

Peluang perpustakaan YPI PIP untuk menjalankan fungsi perpustakaan sebagai agen perubahan social bagi masyarakat Kudus sangat besar. Dengan meninjau karakteristik masyarakat yang religious, maka penyediaan koleksi buku agama khususnya, pengadaan kegiatan-kegiatan seminar, diskusi agama maupun sosial, ekonomi serta budaya akanmenjadi elemen pendukung bagi kebangkitan perpustakaan kembali.

Upaya menghidupkan perpustakaan YPI PIP tidak hanya berkutat pada kegiatan keilmuan saja, namun lebih dari itu dapat dikembangkankegiatan sosial yang berorientasi pada penguatan ekonomi dan pelestarian budaya masayarakat Kudus seperti pengadaan pelatihan kewirausahaan sebagai upaya mendukung falsafah GUSJIGANG yang secara berkesinambungan pula akan menguatkan karakter budaya masayarakat setempat. Namun, harapan tersebut hanya akan menjadi isapan jempol belaka bila tidak ada upaya masyarakat dan khususnya pemerintah setempat untuk menjadi garda terdepan dalam melalukan upaya penguatan fungsi perpustakaan YIP PIP melalui penyediaan sarana dan prasarana yang representatif sehingga perpustakaan YIP PIP mampu menjadi magnet bagi masyarakat Kudus khususnya. Dibutuhkan komitmen pemerintah, tokoh masyarakat, tokoh agama, pengusaha dan semua elemen masyarakat yang memiliki kekuatan kontribusi dalam hal moril, materiil dan spiritual sebagai bentuk dukungan yang nyata. Sebab, berdasarkan informasi yang diperoleh di lapangan, di antara salah satu faktor pemicu keterpurukan perpustakaan YPI PIP adalah melemahnya komitmen dari pemerintah dan para pengelola yang terdiri dari pengusaha-pengusaha besar di Kudus untuk peduli pada

${ }^{15}$ Fuad Hasan, "Perpustakaan Sebagai Pusat pembelajaran dan Agen Perubahan Masyarakat," diakses 5 Juli 2018, https://aurajogja.wordpress.com. 
keberlangsungan kegiatan pendidikan dan peningkatan kualitas intelektual masyarakat melalui peran perpustakaan. Perpustakaan tidak dipandang sebagai unsur yang penting dalam dinamika pembangunan mengingat tidak memberikan kontribusi secara ekonomis. Padahal, sangat dibutuhkan penguatan secara moril dan materiil untuk mewujudkan integrasi teknologi informasi yang komprehensif sebagai sarana pendukung utama yang dilengkapi dengan sumber daya manusia yang kompeten untuk memberikan pelayanan berbasis ilmu perpustakaan. Kesan yang selama ini melekat pada perpustakaan YPI PIP sebagai perpustakaan kuno, jadul, sepi, dan mati suri dapat ditumbangkan dengan inovasiinovasi dan kreatifitas pemerintah, akademisi serta stakeholders yang dibutuhkan sumbangsih pemikiran dan usaha mereka.

Banyak pihak di luar institusi pendidikan yang dapat digaet untuk ikut mengembangkan perpustakaan dengan konsekuensikonsekuensi tertentu. Misalnya dengan pemasangan banner, logo, atau mengadakan events tertentu yang dapat menarik pengunjung dan pihak luar sebagai sponsornya. Banyak events yang dapat digelar untuk menarik pengunjung misalnya; bedah buku, peluncuran buku, seminar, workshop, pentas music, teater, pameran seni, bazaar buku dan lainnya. Selain itu dapat diupayakan kerja sama dengan lembaga lain misalnya: lembaga penelitian, media massa, dan lembaga lainnya yang selalu berkaitan dengan data dokumentasi. ${ }^{16}$ Perwujudan upaya tersebut akan menjadi bukti nyata bahwa kehadiran perpustakaan tidak hanya memiliki fungsi pendidikan, namun juga mampu menjalankan fungsi rekreasi bagi masyarakatnya.

Adapun, untuk inovasi pengembangan perpustakaan melalui pengadaan layanan berbasis IT hendaknya didahului dengan pengayaan koleksi buku dan kelengkapan sarana dan prasarana yang terkait. Upaya inipun harus dilakukan sesuai dengan prosedur dan secara teknis memenuhi standarisasi

16 Darmaningtyas, Perpustakaan dalam Dinamika Pendidikan dan Kemasyarakatan, 89. 
nasional. Lebih lanjut menurut Darmaningtyas menegaskan bahwa pembangunan fasilitas perpustakaan semewah apapun baik di dalam maupun di luar institusi pendidikan tidak akanada artinya apabila tidak diimbangi upaya perubahan paradigma berpikir masyarakatnya. Mungkin hanya sekedar mampu mencapai target pengunjung secara kuantitas saja mengingat perpustakaan dibangun dengan kualitas fisik yang megah, berAC, namun di dalamnya kegiatan literasi tidak berjalan maksimal. Maka menurut peneliti di sini bila ditinjau pada karakteristik masyarakat Kudus yang memiliki karakteristik religious, maka seperti dijelaskan sebelumnya akan banayak celah atau peluang untuk mensinergikan kebutuhan penguatan perpustakaan dengan kebutuhan beragama masyarakat melalui kegiatan yang berorientasi pada kehidupan sosial keagamaan. Bila ditinjau pada era sebelumnya dimana perpustakaan YPI PIP ini sempat memiliki kiprah sebagai pusat kegiatan santunan anak yatim dan dhuafa yang menurut informan kegiatan tersebut masih berjalan hingga saat ini, maka agenda tersebut dapat dilestarikan kembali sebagai bagian dari kegiatan sosial keagamaan yang di desain sedemikian rupa pelaksanaannya sehingga menjadikan realisasi dari peran perpustakaan sebagai media syiar dan penguatan kesejahteraan masyarakat. Bahkanakan lebih baik bila kegiatan tersebut dapat dikembangkanlebih jauh dalam bentuk kegiatan pemberdayaan ekonomi dan kesejahteraan ummat sehingga lebih mengedepankan nilai-nilai kemandirian ekonomi umat Islam di Kudus dan sekitarnya.

Penanaman filosofi hidup yang kuat dalam rumusan GUSJIGANG adalah point yang istimewa bagi masyarakat Kudus. Falsafah ini dapat diimplementasikan pada pembangunan intelektual masyarakat Kudus melalui peran perpustakaan YPI PIP sebagai media yang dapat memfasilitasi upaya pencapaian kualitas masyarakat kudus yang berkarakter mulia (bagus), memiliki wawasan keilmuan yang luas dengan filosofi ngaji nya, memiliki etos kerja yang tinggi (dagang). Kontribusi perpustakaan di sini adalah padaperbaikan dan peningkatan kualitas pelayanan yang 
meliputi pembaruan koleksi buku, pelayanan prima pustakawan yang kompeten berbasis IT. Penyediaan koleksi buku hendaknya terus mengalami pembaharuan dan tidak hanya pada bukubuku bertema agama namun secara berimbang penyediaan buku-buku bacaan ilmu pengetahuan yang bersifat umum perlu diupayakan khususnya buku-buku yang bermuatan penguatan ekonomi melalui kewirausahaan. Namun, hal terpenting adalah bagaimana membangun kesadaran masyarakat atas budaya baca dengan cara meningkatkan minat baca. Meningkatkanminat baca dapat dilakukan melalui pengadaan kegiatan-kegiatan yang berindikasi pengasahan intelektual seperti lomba karya ilmiah, penelitian, lomba debat, lomba mendongeng untuk melatih budaya literasi pada anak yang dapat dilaksanakan dalam saat tertentu seperti pada perayaan hari besar Islam, bulan bahasa, hari buku dan sebagainya.

\section{Simpulan}

Eksistensi perpustakaan dalam rangka membangun kecerdasan bangsa merupakan hal yang tidak dapat ditawar lagi. Sekalipun dalam realitanya, seiring perkembangan arus teknologi informasi yang lebih banyak menyediakan kemudahan dalam pelayanan pemenuhan kebutuhan informasi memberi dampak pada melemahnya peran perpustakaan sebagai penyedia informasi dan pengetahuan masyarakat. Demikianlah yang sedang terjadi pada kondisi perpustakaan YPI PIP (Yayasan Perpustakaan Islam dan Penyiaran Ilmu Pengetahuan) Kabupaten Kudus. Perpustakaan yang pernah Berjaya di era sebelum tahun 2000 an ini mengalami mati suri sebagai akibat dari gencaranya perubahan literasi yang lebih berbasis teknologi informasi.

Banyak faktor yang menjadi penyebab terpuruknya perpustakaan yang didirikan pada tahun 1975 seolah mati segan hidup tak mau. Padahal dimasa kejayaannya, perpustakaan ini mampu menjadi pusat dari kegiatan yang tidak hanya seputar keilmuan namun lebih dari itu mampu menjadi pusat kegiatan 
sosial keagamaan seperti santunan yatim, seminar, diskusi dan lainnya. Keterpurukan perpustakaan ini dipicu oleh banyak factor yang diantaranya karena ketidakmampuan untuk mengikuti perubahan dinamika perpustakaan yang kian maju dan modern, keterbatasan dana yang berimbas pada keterbatasanpenyediaan koleksi buku serta pengadaan sarana dan prasarana lainnya. Lemahnya peran perpustakaan YPI PIP Kudus pun juga diduga karena lemahnya minat baca masyarakat kita yang diperburuk oleh kualitas perpustakaan yang tidak memiliki daya dukung untuk menstimulasi perkembangan minat baca masyarakatnya.

Keterpurukan perpustakaan YPI PIP bukanlah akhir dari perjalanan perpustakaan tertua di Kudus ini. Banyak celah yang dapat dijadikanpotensi untuk menghidupkan kembali peran perpustakaan YPI PIP. Masyarakat Kudus yang religious dengan indikator minat yang tinggi pada majlis taklim, menjamurnya pesantren dan madrasah adalah peluang yang dapat dibidik untuk bekerja sama dalam membangun geliat perpustakaan ini. Menjadikan perpustakaan tidak hanya sebagai sarana penyimpanan buku, namun juga sebagai wahana sumber belajar khususnya untuk memperkaya pengetahuanagama mereka melalui kegiatan keagamaan yang berpusat di perpustakaan adalah salah satu upaya untuk menghidupkan kembali animo masyarakat terhadap perpustakaan. Selain itu, penyelenggaraan event yang bernuansa edukasi, literasi dan enterpreunership dapat dijadikan sebagai wahana untuk mengukuhkan kembali peran perpustakaan YPI PIP dari keterpurukannya.

Dibutuhkan kerja keras dan kerja cerdas dari pegiat perpustakaan, akademisi, tokoh masyarakat, pemerintah, dan semua elemen masyarakat untuk bersama-sama membangun kembali kejayaan perpustakaan YPI PIP yang pada akhirnya kelak akan berkontribusi pada peningkata kualitas intelektual, personal dan spiritual masyarakat Kudus khususnya dan semua elemen bangsa umumnya. 


\section{DAFTAR PUSTAKA}

Anonim. "Perpustakaan Doeloe, Sekarang dan yang Akan Datang." YPPI (Yayasan Pengembangan Perpustakaan Indonesia (blog). Diakses 2 Juli 2018. http://pustakaindonesia.org/ yppi/2013/11/21/perpustakaan-doeloe-sekarang-dan-yangakan-datang/.

Darmaningtyas. Perpustakaan dalam Dinamika Pendidikan dan Kemasyarakatan. Semarang: UNIKA Soegijapranata, 2008.

Elga Andina. "Memotivasi Minat Baca." Info Singkat Kesejahteraan Sosial Vol. 8, No. 22 (November 2016).

Endang Saepuddin. “Tingkat Budaya Membaca masyarakat.” Jurnal Kajian Informasi dan Perpustakaan Vol.3, No. 2 (Desember 2015).

Erik Ismaya, Irfa’i Faturrahman, dan Deka Setiawan. "Makna dan Nilai Buka Luwur Sunan Kudus (Sumbangan Pemikiran Mewujudkan Visi Kampus Kebudayaan)." Jurnal Kredo Vol.1, No.1 (Oktober 2017).

Fuad Hasan. "Perpustakaan Sebagai Pusat pembelajaran dan Agen Perubahan Masyarakat." Diakses 5 Juli 2018. https:// aurajogja.wordpress.com.

Hermawan, dan Zulfikar. Etika Kepustakawanan; suatu Pendekatan Terhadap Kode 'Etik Pustakawan Indonesia. Jakarta: Sagung Seto, 2010.

Imam Arwindra. "Perpustakaan Umum Pertama di Kudus Riwayatmu Kini." Seputar Kudus (blog), 2017. http:// seputarkudus.com/2017/03/perpustakaan-umum-pertamadi-kudus-riwayatmu-kini.html.

Rahmananta. Pedoman Penyelenggaraan Perpustakaan sekolah; Petunjuk Untuk Membina, Memakai dan memelihara Perpustakaan di Madrasah. Jakarta: Perpustakaan Nasional RI, 1995. 
Saefudin. "Strategi Pengembangan Perpustakaan Perguruan Tinggi Dalam Memenuhi Kebutuhan Informasi Di Era Digital (Sebuah Pandangan Sosiologis atas Fenomena Spiritual Seekers Di Dunia Maya)." Journal Libraria Vol. 4. No. 1 (2016).

Tafrikhuddin. "Antologi Ilmu Perpustakaan dan Informasi." Pascasarjana UIN Sunan Kalijaga, 2015.

Triana Santi. "Penerapan Teknologi Informasi Untuk Meningkatkan Kualitas Layanan Perpustakaan IAIN Sumatera Utara." Jurnal IQRA' Vol.2, No. 2 (2008).

Trucker R. N. The Organization and Management of Educational Technology (New patterns of learning). London: Croom Helm, 1979.

Visi Pustaka Vol.7 No. 1 (Juni 2005). 